
13 (1985) 305
J. Perinat. Med.

\section{Ultrasonic measurement of the growth of fetal limb bones in normal pregnancy}

\author{
E. P. Issel
}

Department of Gynecology and Obstetrics (Director: Prof. Dr. K. Rothe), Division of Obstetrics (Head: Prof. Dr. W. Krause), Martin Luther University, Halle-Wittenberg, German Democratic Republic

\section{Introduction}

The measurement of the long bones of the extremities is being increasingly incorporated into the ultrasonic evaluation for fetal development and diagnosis of fetal anomalies. Several authors have published data for normal values [1, 4-7]. Their results differ in several areas, and we will discuss in detail these differences in correlation with our own material. Our study had the following objectives:

1. With which published data are our own values in best agreement?

2. Which mathematical formula derived from the computer analysis of the results is best for the determination of gestational age? Specifically we aimed to address the question whether a linear correlation is adequate or whether a polynomial curve should be established.

3. The examination of the statement of others $[6,7]$ that the radius and ulna, and tibia and fibula respectively have identical lengths ultrasonically.

\section{Material and methods}

In order to measure the bony diaphysis of the long bones of the extremities we used the ultrasound B apparatus "Sonodiagnost R"
(Manufacturer: Philips) with a focused linear realtime scanner of $3.0 \mathrm{MHz}$. The speed of sound is assumed to be $1540 \mathrm{~m} / \mathrm{second}$. In order to test the accuracy of our measurements we measured the long bones of three dead fetuses sonographically. These values were compared with the direct measurements on the disected extremity bones (Tab. I).

We selected at random, for each week of gestation between the 17 th and 41 st week, 40 cases out of a total of 2500 cases with extremity measurements in normal pregnancies. Thus, there were 1000 measurements for each bone within this range of gestation. A normal pregnancy was defined as a gestation in which the mother was free of serious illness, in which there was no fetal anomaly and in whom the biparietal diameter as well as the midthoracic diameter (at the plane of the insertion of the umbilical vein into the hepatic sinus) was between the 25 th and 75 th percentiles. This correlates approximately to a standard deviation of \pm one week in the second trimester and \pm two weeks in the third trimester of gestation. Curves for normal values were achieved by plotting the data for the $10 \mathrm{th}, 50 \mathrm{th}$ and 90th percentiles (P 10, P 25, P 50) for each bone. This was smoothed by averaging the five data points. Values for the 42nd and for the 14-16th gestational weeks were entered as dotted lines because they could not be assumed to 
Tab. I. Comparison of sonographic measurements of the extremities with direct measurements on three stillborn fetuses (measurements in $\mathrm{cm}$ ).

\begin{tabular}{lllll}
\hline & Bone & $\begin{array}{l}\text { Total length } \\
\text { of the dissected } \\
\text { bone }\end{array}$ & $\begin{array}{l}\text { Length of the } \\
\text { diaphysis of the } \\
\text { longitudinally } \\
\text { sawed bone }\end{array}$ & $\begin{array}{l}\text { Sonographically } \\
\text { determined } \\
\text { length of the bone }\end{array}$ \\
\hline Case 1 & Humerus & 6.2 & 4.8 & 5.1 \\
$1300 \mathrm{~g}$ & Ulna & 5.4 & 4.7 & 4.7 \\
& Radius & 4.5 & 4.1 & 4.1 \\
& Femur & 7.0 & 5.7 & 5.6 \\
& Tibia & 6.1 & 4.9 & 4.8 \\
\hline Case 2 & Fibula & 6.0 & 4.9 & 4.8 \\
$3050 \mathrm{~g}$ & Humerus & 8.3 & 6.8 & 6.6 \\
& Ulna & 7.2 & 6.1 & $?$ \\
& Radius & 6.3 & 5.2 & 8.0 \\
& Femur & 10.3 & 8.1 & 6.6 \\
\hline Case 3 & Tibia & 8.3 & 6.7 & 6.6 \\
\hline $410 \mathrm{~g}$ & Fibula & 7.6 & 6.7 & 5.9 \\
& Humerus & 7.4 & 6.0 & 5.8 \\
& Ulna & 6.7 & 5.6 & 6.1 \\
& Radius & 5.7 & 4.9 & 6.7 \\
& Femur & 8.6 & 6.9 & 5.9 \\
\hline
\end{tabular}

be technically as accurate as the data from the 17 th -41 st weeks. Since labor is often medically induced after the 42 nd week with a favorable BISHOP score the distribution of the gestational age for the single days of this gestational week declines markedly towards it end. Thus duration of pregnancy is not as equally distributed as the material in the other gestational weeks. Furthermore in this group there are cases in which the patient deliberately identified her last period as $1-2$ weeks ealier. This is due to the fact that the leave from work for pregnancy in the German Democratic Republic begins six weeks before the calculated date of confinement. Therefore some extrapolations were necessary for smoothening the curve.

Similar extrapolation for $\mathrm{P} 10$ and $\mathrm{P} 90$ was performed resulting in a slight narrowing of the distances of the curve from the P 50 between the 14 th and 16th gestational week. In this range the measurement accuracy which is $\pm 2 \mathrm{~mm}$ due to the resolution of the sonographic apparatus becomes noticeable as a larger coefficient of variation. This phenomenon has also been noted by other $[5,6,7]$. Thus the coefficient of variation for the femur at 28 weeks is $4 \%$ and at 12 weeks it is $15 \%$. In order to determine by regression analysis, the mathematical correlation between duration of pregnancy and the length of the extremity bones, the unsmoothened values of the P 50 (Tab. II) were used.

\section{Results}

Tab. 1 compares the results of the sonographic measurements of long bones in dead fetuses with postnatal direct measurement values. It is seen that the proportion of the bony diaphysis to the entire bone is measured very accurately by ultrasound. The dimensions for the length of the entire bone including the cartilagineous epiphysis are considerably larger. 
Tab. 11. Measurement of long arm bones between 17 th and 41 st week in normal pregnancics.

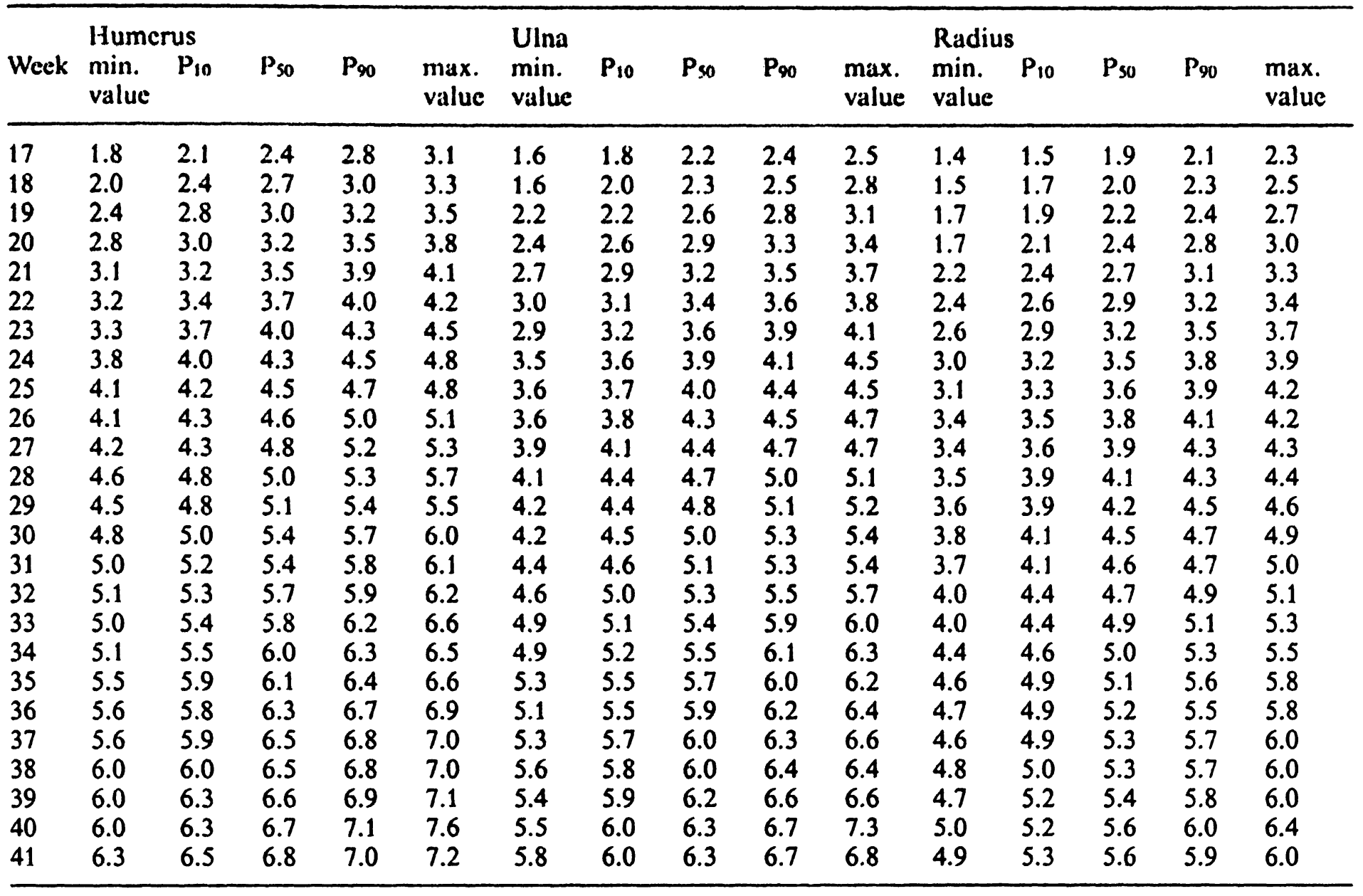

Only in one case of the 16 bones measured was there a deviation of $3 \mathrm{~mm}$, and in six other cases there was a deviation of $2 \mathrm{~mm}$ between the sonographic and the real measurements.
The other nine cases deviated by $\pm 1 \mathrm{~mm}$. We determined unequivocally that the radius is shorter than the ulna in both sonographic and direct measurements (Figs. 1 and 2). In con-
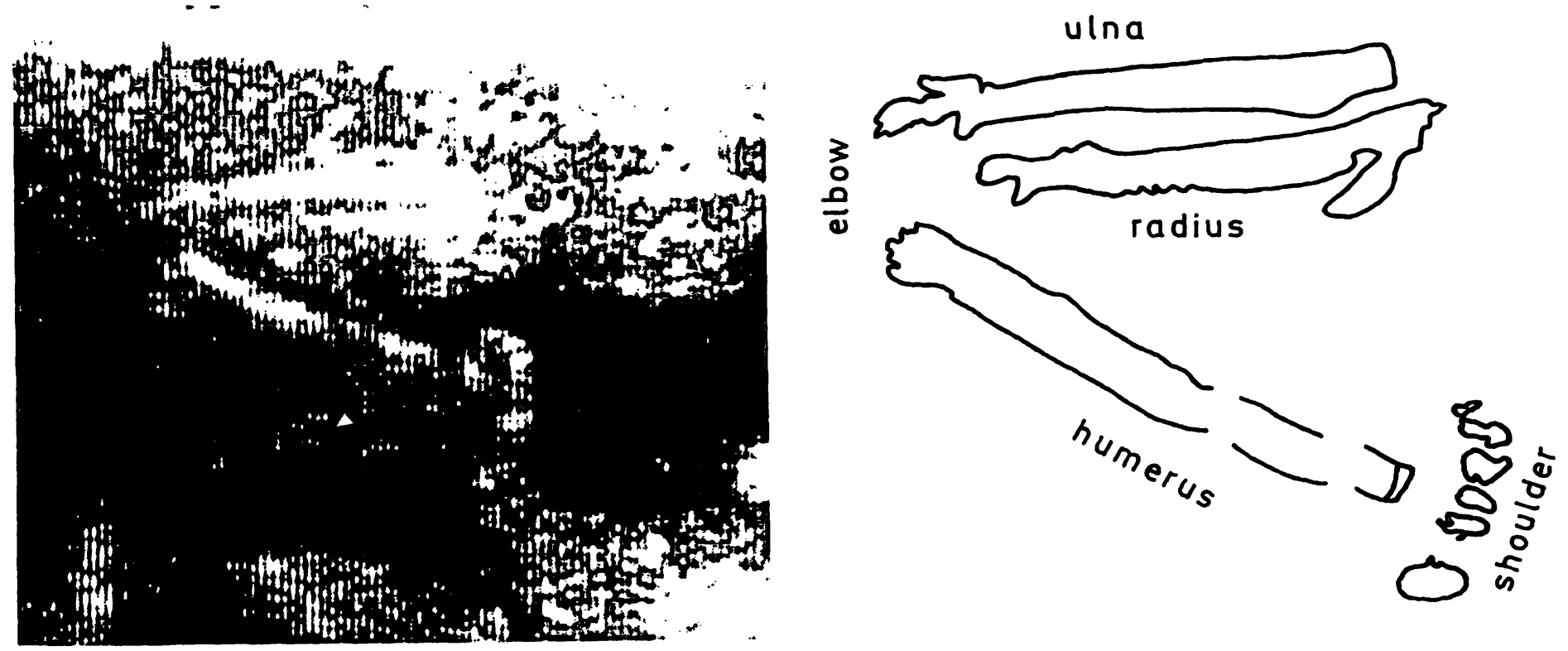

Fig. 1. Flexed arm at 24 weeks. Ulna $=3.9 \mathrm{~cm}$, Radius $=3.3 \mathrm{~cm}$, Humerus $=4.2 \mathrm{~cm}$. 

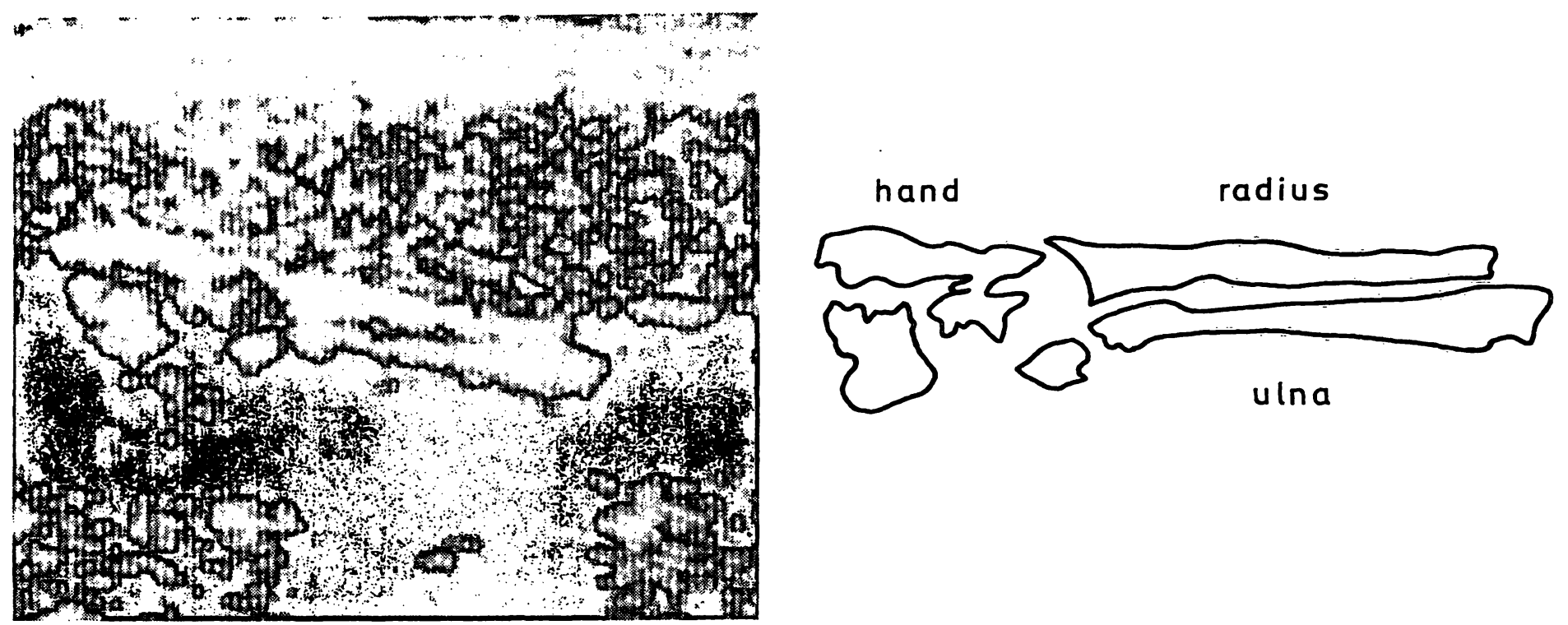

Fig. 2. Forearm at 21 weeks. Radius $=2.9 \mathrm{~cm}$, Ulna $=3.2 \mathrm{~cm}$.

trast, the bony diaphysis of the tibia and fibula are equally long (Fig. 3). After obtaining similar results in 50 cases with a deviation of $\pm 1 \mathrm{~mm}$, we terminated the series.
Results of the normal data for the length of the long bones between the 17 th and 41 st complete gestation weeks are summarized in Tabs. II and III for arms and legs. These data indicate that

Tab. III. Measurement of the long leg bones between the 17th and 41st normal pregnancy week.

\begin{tabular}{|c|c|c|c|c|c|c|c|c|c|c|}
\hline Week & $\begin{array}{l}\text { Femur } \\
\text { min. } \\
\text { value }\end{array}$ & $\mathbf{P}_{10}$ & $P_{50}$ & $\mathrm{P}_{90}$ & $\begin{array}{l}\text { max. } \\
\text { value }\end{array}$ & $\begin{array}{l}\text { Tibia } \\
\text { min. } \\
\text { value }\end{array}$ & $P_{10}$ & $\mathrm{P}_{50}$ & $P_{90}$ & $\begin{array}{l}\max . \\
\text { value }\end{array}$ \\
\hline 17 & 1.9 & 2.2 & 2.5 & 2.8 & 3.0 & 1.5 & 1.8 & 2.2 & 2.5 & 2.6 \\
\hline 18 & 2.0 & 2.4 & 2.8 & 3.1 & 3.2 & 1.7 & 2.0 & 2.3 & 2.5 & 2.8 \\
\hline 19 & 2.4 & 2.8 & 3.0 & 3.3 & 3.5 & 2.0 & 2.3 & 2.6 & 2.8 & 3.1 \\
\hline 20 & 3.0 & 3.1 & 3.4 & 3.7 & 3.8 & 2.5 & 2.6 & 2.9 & 3.2 & 3.4 \\
\hline 21 & 3.1 & 3.2 & 3.6 & 4.1 & 4.4 & 2.5 & 2.8 & 3.2 & 3.4 & 3.5 \\
\hline 22 & 3.5 & 3.7 & 3.9 & 4.2 & 4.5 & 2.8 & 3.1 & 3.3 & 3.6 & 4.1 \\
\hline 23 & 3.7 & 4.0 & 4.3 & 4.5 & 4.7 & 3.1 & 3.4 & 3.7 & 3.8 & 4.1 \\
\hline 24 & 4.2 & 4.3 & 4.5 & 4.8 & 4.9 & 3.5 & 3.6 & 3.9 & 4.2 & 4.5 \\
\hline 25 & 4.2 & 4.4 & 4.7 & 5.1 & 5.3 & 3.4 & 3.8 & 4.1 & 4.5 & 4.6 \\
\hline 26 & 4.5 & 4.7 & 5.0 & 5.3 & 5.6 & 3.9 & 4.0 & 4.3 & 4.7 & 4.8 \\
\hline 27 & 4.5 & 4.7 & 5.2 & 5.6 & 5.8 & 3.8 & 4.1 & 4.5 & 4.8 & 5.0 \\
\hline 28 & 4.9 & 5.2 & 5.4 & 5.7 & 6.0 & 4.0 & 4.4 & 4.6 & 4.9 & 5.3 \\
\hline 29 & 5.0 & 5.3 & 5.7 & 6.0 & 6.2 & 4.2 & 4.6 & 4.9 & 5.1 & 5.4 \\
\hline 30 & 5.3 & 5.5 & 5.9 & 6.2 & 6.3 & 4.4 & 4.8 & 5.0 & 5.4 & 5.7 \\
\hline 31 & 5.4 & 5.6 & 6.0 & 6.2 & 6.5 & 4.7 & 4.8 & 5.2 & 5.5 & 5.8 \\
\hline 32 & 5.9 & 6.0 & 6.3 & 6.6 & 7.0 & 5.0 & 5.1 & 5.5 & 5.8 & 5.9 \\
\hline 33 & 5.7 & 6.0 & 6.4 & 6.9 & 7.2 & 4.7 & 5.2 & 5.6 & 5.9 & 6.1 \\
\hline 34 & 6.1 & 6.2 & 6.6 & 7.1 & 7.3 & 4.9 & 5.1 & 5.7 & 6.1 & 6.5 \\
\hline 35 & 6.3 & 6.5 & 6.8 & 7.3 & 7.6 & 5.1 & 5.5 & 5.9 & 6.2 & 6.6 \\
\hline 36 & 6.4 & 6.8 & 7.2 & 7.4 & 7.8 & 5.6 & 5.6 & 6.1 & 6.4 & 6.5 \\
\hline 37 & 6.5 & 6.8 & 7.4 & 7.8 & 8.1 & 5.3 & 5.7 & 6.2 & 6.5 & 6.8 \\
\hline 38 & 6.8 & 7.0 & 7.3 & 7.6 & 7.9 & 5.8 & 6.0 & 6.2 & 6.5 & 6.7 \\
\hline 39 & 6.9 & 7.1 & 7.4 & 8.0 & 8.5 & 5.7 & 6.1 & 6.3 & 6.7 & 6.8 \\
\hline 40 & 6.9 & 7.3 & 7.6 & 8.2 & 8.5 & 5.8 & 6.1 & 6.4 & 6.8 & 6.9 \\
\hline 41 & 7.0 & 7.4 & 7.7 & 8.2 & 8.3 & 5.9 & 6.3 & 6.5 & 6.8 & 6.9 \\
\hline
\end{tabular}




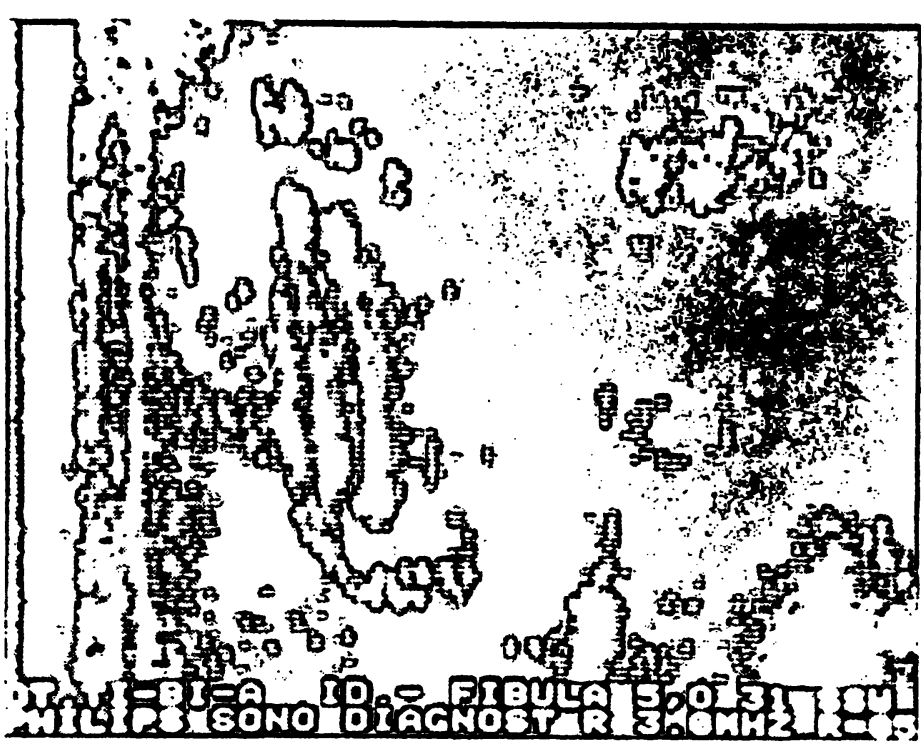

Fig. 3. Lower leg at 31 weeks. Tibia and fibula are equally long and measure $5.0 \mathrm{~cm}$.

the 50th percentile rises continually without much need for smoothing the curve. The values for the 10th and 90th percentile vary only slightly more. Likewise, the minimal and maximum measurements do not show extreme deviations and fit well to the normal curves. The deviations for the minimum and maximum values are mostly within $2-4 \mathrm{~mm}$ above the 90 th or below the 10 th percentile.

Only in four cases was this deviation $5 \mathrm{~mm}$ and in one $6 \mathrm{~mm}$; thus, our results appear that they can be considered as within normal limits.

The smoothened normal curves for the long bones are shown in Figs. 4-8. The growth rate for the femur is greater than that for the other

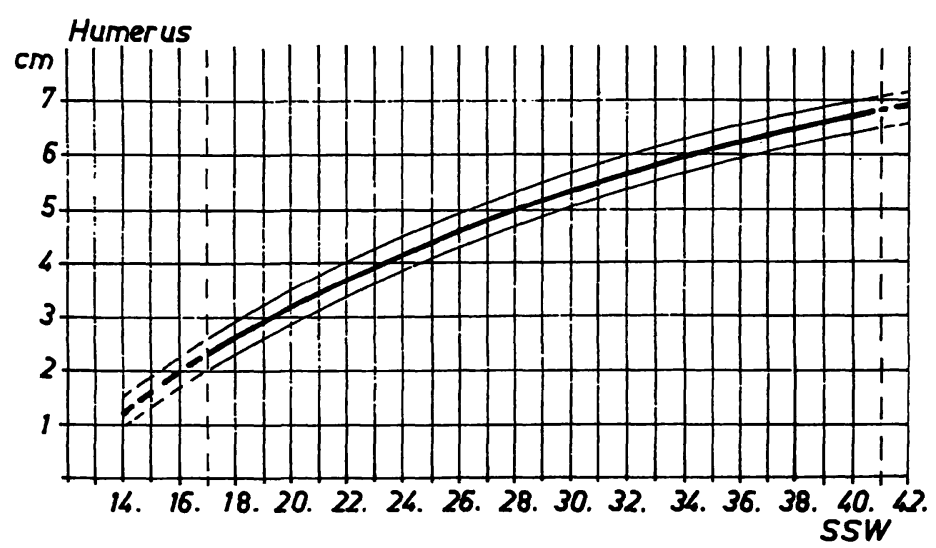

Fig. 4. Normal curves for growth of the humerus. Indicated are 10th, 50th, and 90th percentile. Dotted curves were obtained by extrapolation. SSW: gestational week.

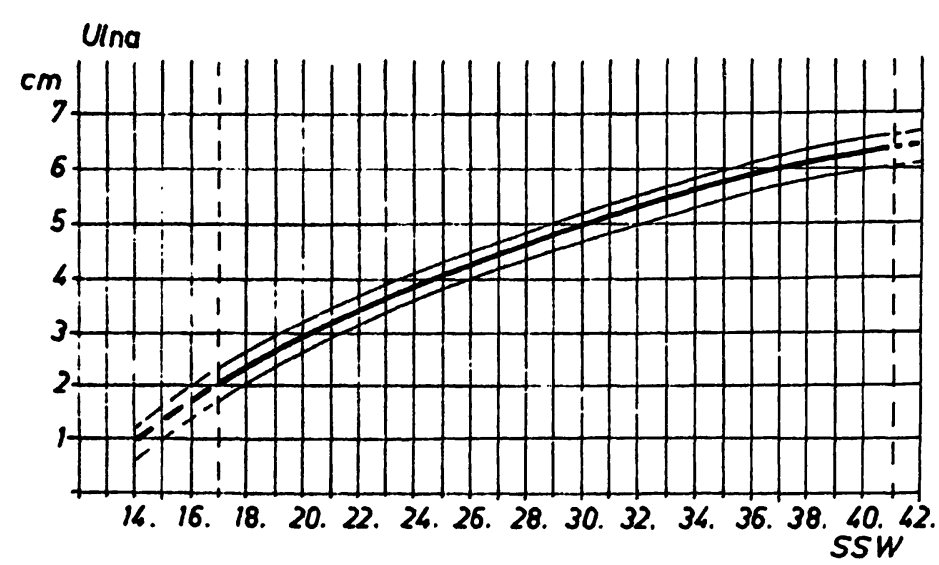

Fig. 5. Normal curves for growth of the ulna. SSW: gestational week.

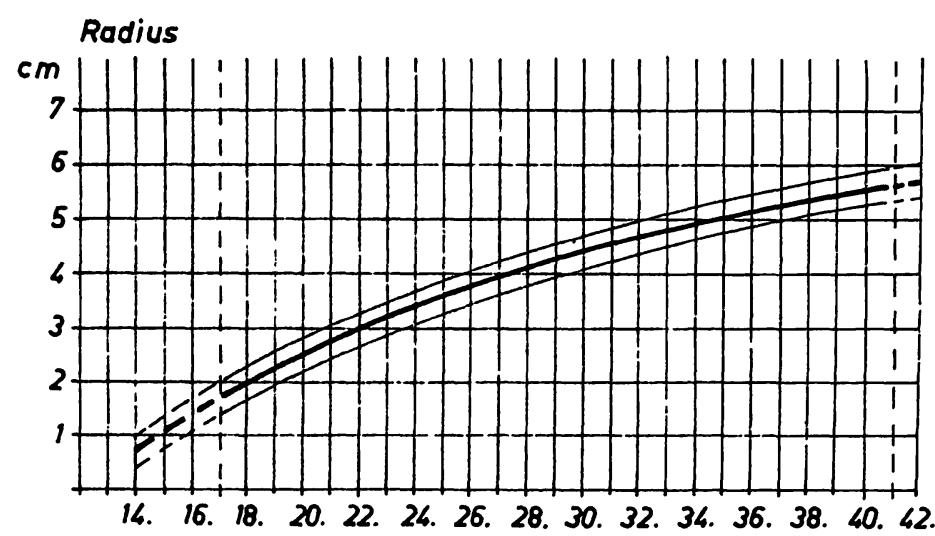

SSW

Fig. 6. Normal curves for growth of the radius. SSW: gestational week.

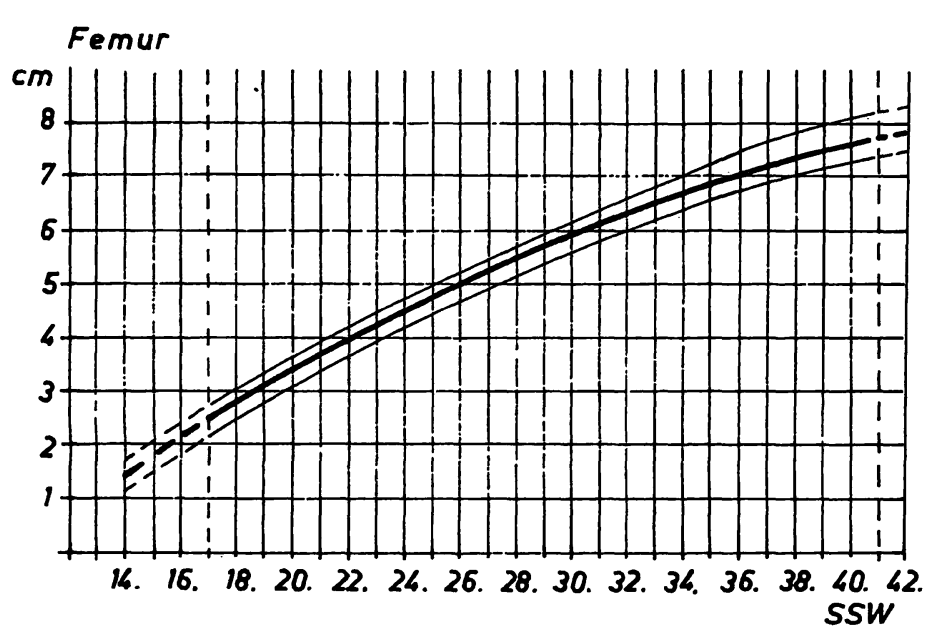

Fig. 7. Normal curves for growth of the femur. SSW: gestational week.

four bones (humerus, radius, ulna, tibia) which have similar growth rates. The latter four bones have a growth rate of $3 \mathrm{~mm}$ per week in early pregnancy when it is noticably greater than 


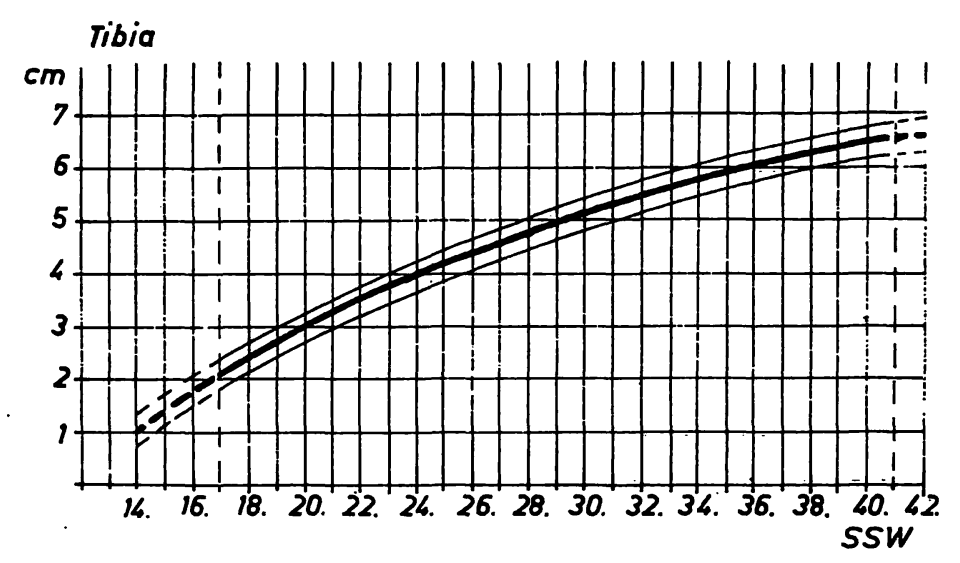

Fig. 8. Normal curves for growth of the tibia. SSW: gestational week.

Tab. IV. Calculation of gestational age from extremity bones.

$\begin{aligned} \text { Gestational age in weeks } & =0.5611 \mathrm{HUM}^{2} \\ & +0.1690 \mathrm{HUM} \\ & +13,247 \\ & =0.6275 \mathrm{ULNA}^{2} \\ & +0.2313 \mathrm{ULNA}^{2} \\ & +13.647 \\ & =0.7692 \mathrm{RAG}^{2} \\ & +0.3370 \mathrm{RAD} \\ & +13.856 \\ & =0.3134 \mathrm{FEM}^{2} \\ & +0.1276 \mathrm{FEM} \\ & +11.883 \\ & =0.5312 \mathrm{TIB}^{2} \\ & +0.6766 \mathrm{TIB} \\ & +13.223\end{aligned}$

Tab. V. Calculation of the length of the extremity bones from the gestational week.

\begin{aligned} & \hline Humerus in $\mathrm{cm}=0.4406 \mathrm{~W} \\ &-0.00442 \mathrm{~W}^{2} \\ &-3.85 \\ &=0.4391 \mathrm{~W} \\ &-0.00451 \mathrm{~W}^{2} \\ &-4.11 \\ &$ Ulna in cm $=0.4010 \mathrm{~W} \\ &$ Radius in cm $-0.00413 \mathrm{~W}^{2} \\ &-3.87 \\ &$ Femur in cm $=0.4546 \mathrm{~W} \\ &-00405 \mathrm{~W}^{2} \\ &$ Tibia in $\mathrm{cm}=0.11 \\ &=0.4410 \mathrm{~W} \\ &-0.00439 \mathrm{~W}^{2} \\ &-4.18 \\ &$\hline\end{aligned}

towards the end of pregnancy where there is only a $1 \mathrm{~mm}$ growth per week. It follows that in order to calculate the relation between gestational age and bone length, polynomial formulas must be applied to all long bones in order to be valid for the entire duration of pregnancy. The correlation between the duration of gestation and the longitudinal measurements of the bones are seen in Tabs. IV and V.

\section{Discussion}

The accuracy of sonographic measurements of fetal extremity bones have also been investigated by SCHLENSKER [6] and QUEENAN [5]. SCHLENSKER [6] proceeded as we did and obtained direct measurements on bone preparations from stillbirths. QUEENAN et al. [5] validated their sonographic data by comparing them with radiographs on stillborn fetuses. These authors concur that the accuracy of sonographic measurements is $\pm 2 \mathrm{~mm}$. Using our ultrasound equipment, the extremities can be visualized under optimal conditions from the 8 th week on when the crown rump length is $1.4-1.6 \mathrm{~cm}$. Extremity bones in their entirety can be determined from the 10 th week on (crown rump length $2.5 \mathrm{~cm}$ ) when their length is about $1.0 \mathrm{~cm}$.

After the 12th week, it is possible to differentiate upper and lower arms and legs. Only in exceptional cases were we able to isolate radius from ulna before the 13 th week. In contrast to other investigators, we find that the accuracy of measurement before the 14th week is too poor for use in dating pregnancies. In the 14th -16 th weeks reproducable data for the long bones can usually be obtained but the accuracy of the measurement is in the range of the biological variability. Consequently pathological values for extremity measurements with therapeutic consequences (e. g., termination of pregnancy) can be made only from the 17 th week on. However, malformation of extremities generally do not occur in isolation so that this is not generally a management dilemma. 
Our results are closest to those of SCHLENSKER [6] except for the radius and ulna. The difference of his values with our P 50 is generally $\pm 1 \mathrm{~mm}$. The values published by QUEENAN et al. [5], Hohler and QueTal [3], Hobbins [2], and Terinde et al. [7] are generally 1 to $3 \mathrm{~mm}$ above those obtained by us. The data by JEANTY et al. [4] at 18 weeks are $2-3 \mathrm{~mm}$ above our values but by the 34th week $2 \mathrm{~mm}$ below them. It can be concluded from these comparisons that uniform normal curves for the growth of the fetal extremities are valid for Europe and North America.

The biological standard deviations from the mean as expressed by the distance of the 10th and 90th percentile from the 50th percentile show greater differences between the various authors. This biological variation apparently is related to size and selection of the underlying case material. The distance between the 10th and 50th and between the 90th and 50th percentile are mostly $3-4 \mathrm{~mm}$ and correspond to the data from HoHLER and QueTAL [3] who indicate distances of the 5 th and 95 th percentile to the 50th percentile with $3-5 \mathrm{~mm}$.

JEANTY et al. [4] and HobBINS et al. [2] indicate these variations with $7-8 \mathrm{~mm}$. The values for two standard deviations frequently found in the literature $[5,6,7]$ are generally between 2 and $8 \mathrm{~mm}$ and increase with duration of pregnancy. We suggest that data with the following characteristics should be critically reviewed, namely,

\section{Summary}

From sonographic measurements, normal curves for the fetal growth of extremity bones (humerus, ulna, radius, femur, tibia) were established. They are based on 40 measurements for each bone weekly between the 17 th and 41 th gestational week. Tabs. II and III summarize the data. Figs. 4-8 furnish the smoothened normal curves for 10th, 50th and 90th percentile. Values for the 14-16 and the 42nd week were extrapolated from the results and the course of the curves.

A comparison of sonographic measurements with findings from dissected stillborn fetuses (Tab. I) demonstrated an accuracy of the sonographic measurements of $\pm 2 \mathrm{~mm}$. We established that the radius is significantly those where (1) the standard deviations fluctuate markedly from week to week; (2) the standard deviations are larger in earlier pregnancy than in later pregnancy and (3) radius and ulna are indicated as being equally long $[6$, 7].

The estimation of the mean pregnancy duration from the length of the femur was published by HOHLER and QUETAL [3]. We recalculated their data with the same polynomial equation (Tab. IV) and found a virtual likeness between the two formulas with a difference of less than one half week.

The estimation of the mean length of the long bones from the actual gestational age was published by JEANTY et al. [4]. We entered the same polynomial equation into our equation and arrived at the same results for femur and tibia with a deviation for each week of gestation within $2 \mathrm{~mm}$. For the humerus, ulna and radius the correlations are different. Whereas our results at 20 weeks correspond with the length of bones indicated by JEANTY et al. [4] our values rise more steeply in the course of the pregnancy than those according to the formula of JEANTY et al., and at 40 weeks our data are $4-6 \mathrm{~mm}$ above them.

We conclude that in addition to the biparietal diameter and the diameters for the thorax and abdomen, the values for the extremity bones are suitable for the determination of the gestational age.

shorter than the ulna (Figs. 1 and 2) whereas tibia and fibula are of identical length (Fig. 3). The growth rate of the femur throughout pregnancy is greater than that of the other bones. The mathematical correlation between pregnancy duration and length of bones is best described by polynomial formulas (Tabs. IV and V), because the growth rate declines from $4 \mathrm{~mm}$ per week in early mid-trimester to $1 \mathrm{~mm}$ per week toward the end of the third trimester. A comparison with other published data shows the values in the current study to be within the range of variability of these publications. Sonographic measurements of extremity bones are suitable for determining gestational age.

Keywords: Extremity bones, fetus, intrauterine growth, normal curves, sonographic mcasurement. 


\section{Zusammenfassung}

Normalwerte für das Wachstum der Extremitätenknochen in der Fetalzeit

Für das Wachstum der fetalen Extremitätenknochen (Humerus, Ulna, Radius, Femur, Tibia) werden Normkurven von Ultraschallmessungen mitgeteilt. Diese resultieren aus je 40 Meßwerten pro Knochen und Woche zwischen 17 und 41 Schwangerschaftswochen. Die gefundenen Werte sind in den Tabellen II und III zusammengefaßt. Die geglätteten Normkurven (Abb. 4 bis 8 ) geben die $\mathrm{P}_{10}, \mathrm{P}_{50}$ und $\mathrm{P}_{90}$ wieder. Die dort gestrichelt eingetragenen Werte für 14-16 und 42 Wochen sind entsprechend dem Gesamtkurvenverlauf in Verbindung mit den eigenen Meßwerten etwas extrapoliert.

Der Vergleich von Ultraschallmessungen bei antenatal abgestorbenem Fetus mit den Obduktionspräparaten (Tab. I) ergab eine Genauigkeit der Ultraschallmessun- gen von $\pm 2 \mathrm{~mm}$. Ferner stellten wir fest, daß der Radius deutlich kürzer ist als die Ulna (Abb. 1 und 2). Demgegenüber haben Tibia und Fibula die gleiche Länge (Abb. 3). Die Wachstumsgeschwindigkeit des Femur liegt im Verlauf der Schwangerschaft über der der anderen Knochen. Zur Beschreibung der mathematischen Beziehungen zwischen Schwangerschaftsdauer und Knochenlänge müssen Formeln mit Polynomcharakter verwendet werden (Tab. IV und V), da die Wachstumsgeschwindigkeit von etwa $4 \mathrm{~mm}$ pro Woche am Beginn des 2 . Trimesters auf etwa $1 \mathrm{~mm}$ pro Woche am Ende des 3. Trimesters abnimmt. Ein Vergleich mit den Angaben aus der Literatur zeigt, daß unsere Werte im Schwankungsbereich dieser Mitteilungen liegen. Die ultrasonographischen Meßwerte der Extremitätenknochen können zur Bestimmung des fetalen Gestationsalters mit herangezogen werden.

'Schlüsselwörter: Extremitätenknochen, Fet, intrauterines Wachstum, Normkurven, Ultraschallmessung.

\section{Résumé}

Mesure échographique de la croissance osseuse des membres du fetus au cours de la grossesse normale

On a établi à partir de mesures échographiques les courbes normales de la croissance fotale des os des membres (humerus, cubitus, radius, femur, tibia). Ces courbes sont fondées pour chaque os sur 40 mesures effectuées chaque semaine entre la 17ème et la 41ème semaine de gestation. Les résultats sont résumés dans les tableaux II et III. Les courbes normales lissées pour les 10ème, 50 ème et 90ème percentiles sont reproduites dans les figures 4-8. On a extrapolé à partir des résultats et de l'aspect des courbes les valeurs pour la 14ème, la 15 ème, la 16ème et la 42ème semaine.

La comparaison des mesures échographiques avec les données provenant des autopsies de fœtus mort-nés (Tableau I) a démontré une fiabilité des mesures échographi- ques de $\pm 2 \mathrm{~mm}$. Nous avons établi que le radius est de façon significative plus court que le cubitus (Fig. 1 et 2) alors que le tibia et le péroné ont la même longueur (Fig. 3). Le taux de croissance du fémur tout au long de la grossesse est plus élevé que des autres os. La corrélation mathématique entre la durée de la grossesse et la longueur osseuse est décrite au mieux par des formules polynomiales (Tableaux IV et V), en effet, le taux de croissance chute de $4 \mathrm{~mm}$ par semaine au début du second trimestre à $1 \mathrm{~mm}$ par semaine vers la fin $\mathrm{du}$ troisième trimestre. La comparaison avec les autres données montre que les valeurs de notre étude actuelle sont situées à l'intérieur de l'intervalle de variabilité de ces publications. Les mesures échographiques des extrémités osseuses sont adaptées pour la détermination de l'âge gestationnel.

Mots-clés: Extrémités osseuses, fœtus, croissance intra-utérine, courbes normales, mesures échographiques.

Acknowledgements: We thank the members of the Institute of Pathology of the Martin Luther University (Director: Prof. Dr. D. STILlER) for dissection and preparation of the bones and Dr. J. HARRTiNG of the Institute for Biostatistics and Medical Information of the Martin Luther University (Director: Prof. Dr. J. ADAM) for calculating the regression data.

\section{Bibliography}

[1] Ferrant, P., H. B. Meire: Ultrasound measurement of fetal limb lengths. Br. J. Radiol. 5 (1981) 660

[2] Hobins, J. C., M. B. Bracken, M. J. Mahoney: Diagnosis of fetal skeletal dysplasias with ultrasound. Am. J. Obstet. Gynecol. 142 (1982) 306
[3] Hohler, C. W., T. A. Quetel: Fetal femur length: Equations for computer calculation of gestational age from ultrasound measurements. Am. J. Obstet. Gynecol. 143 (1982) 479

[4] Jeanty, P., M. Dramaix-Wilmet, J. V. Kerkem, P. Petroons, J.SchWERs: Ultrasonic evaluation of 
fetal limb growth. Part. II. Radiology 143 (1982) 751

[5] Queenan, J. T., G. D. O'Brien, S. Campbell: Ultrasound measurement of fetal limb bones. Am. J. Obstet. Gynecol. 138 (1980) 297

[6] SCHLENSKER, K.-H.: Die sonographische Darstellung der fetalen Extremitäten im mittleren Trimenon. Geburtshilfe Frauenheilkd. 41 (1981) 366
[7] Terinde, R., E. Driedger, J. E. A. Müller, P. KoZlOWSKI, I. SCHADEWALDT: Extremitätenwachstum, Gestationsalter-Schätzung und Mißbildungsdiagnostik durch Ultraschall-Vermessung fetaler Knochen im II. Trimenon. Z. Geburtshilfe Perinatol. 186 (1982) 125

Received June 12, 1984. Accepted September 4, 1984.

Dr. sc. med. E. P. Issel

Universitäts-Frauenklinik

DDR-4020 Halle

Leninallee 24

German Democratic Republic 